\title{
Comparative media: Vremya's manipulation of foreign conflict reporting in Russia in the context of Western news providers
}

\author{
EMMA HEYWOOD \\ University of Manchester
}

Celebrations surrounding Israel's Sixtieth Anniversary were held 8 May 2008 and were attended by heads of state and government officials from all over the world. It was reported widely in many countries and was marked by a two-day national holiday with memorial services, military displays, and concerts. This paper uses these events as a case study to analyse the cultural shaping of foreign conflict television coverage and compares the foreign news reports of V remya - the flagship evening news provider of Russia's Channel 1 - with that of two other European broadcasters from France and the UK, which are obliged to adhere to strict guidelines. The case study seeks to demonstrate how the Russian state-aligned news provider can promote its home country, whilst negotiating the complex combination of the influential Russian-speaking diaspora in Israel and Russia's multi-layered cross-cultural connections. The paper also discusses how varying constraints imposed by broadcasting regulations can result in differing portrayals of the same event.

\section{INTRODUCTION}

Foreign conflict reporting has been widely discussed in academic scholarship particularly in the post-9/11 era, with coverage of the Iraq War being examined in detail. ${ }^{1}$ Yet, to a large extent, much of this scholarship has focused on American media and its responses to wars in which the US has directly participated. Crosscultural comparisons of television - rather than printed - news media are less common. A valuable contribution to the existing scholarship is therefore made by comparative research, excluding America, but including a media system not conventionally considered Western, such as that of Russia. A cross-linguistic approach is additionally beneficial, as this allows for commentaries and reports, which are not solely based on English language sources. The many advantages of comparative studies are explained by Hallin and Mancini, who advocate the view that such studies enable a shift from ethnocentrism and incorporate the experiences of other national media, rather than generalising those of just one country. ${ }^{2}$ The

\footnotetext{
${ }^{1}$ See the following: War and the Media, ed. by Daya Kishan Thussu and Des Freedman (London: Sage, 2003); Andrew Hoskins and Ben O'Loughlin, Television and Terror: Conflicting Times and the Crisis of News Discourse, New Security Challenges series, ed. by Stuart Croft (Hants: Palgrave Macmillan, 2009); Philip Hammond, Framing Post-Cold War Conflicts (Manchester: Manchester University Press, 2007). ${ }^{2}$ Daniel Hallin and Paolo Mancini, Comparing Media Systems - Three Models of Media and Politics (Cambridge: Cambridge University Press, 2004).

(C) School of Slavonic and East European Studies, University College London, 2014.
} 
comparison of the representations of war and conflict by Russian, French and UK television media systems is therefore valuable. This particular combination is rare, although comparative analysis of news coverage by broadcasters from these countries has been conducted focusing on Islam and security rather than on military conflicts. ${ }^{3}$

The case study used for this article is part of a larger comparative project which analyses a catalogue of over 30,000 news programmes from the above news providers, recorded between November 2006 and September 2008. These news programmes were analysed to compare the foreign conflict reporting of three broadcasters from different countries to examine their news values and the many influences on their coverage in the post-9/11 and post-Cold War era. The news providers are: Vremya, from Russia's Channel 1, a national state-aligned broadcaster; News at Ten from the nominally independent BBC, representing a British public service broadcaster; and the more centrally oriented 20 Heures, representing France, another EU member and also a public service broadcaster, from a media system with a long history of state intervention. Using a comparative approach, it will be possible to highlight certain characteristics of Vremya which might not be revealed if analysed in isolation. Also, similarities and differences in reporting may be determined with the other two news providers, both of which are European, so as to either confirm or challenge the conventional perception of Russian state-aligned television

The principal case study used by the project to analyse foreign conflict reporting is the Middle East. Although there are many definitions of this region, for the purposes of this analysis, this term is applied as being inclusive of Israel, the Palestinian territories, and Lebanon. The region is subject to an on-going conflict, with origins pre-dating the change in East-West relations and also the events of 9/11 and acts as a meeting point of many of the geo-political and post-imperial global struggles facing the three selected news reporting countries, domestically and internationally, forcing them also to confront political legacies inherited from previous regimes. ${ }^{4}$ Lebanon was included due to the effects of, and portrayal of, the Lebanon-Israel war of July 2006, immediately prior to the current period of study, as it continued to be covered for many months by the broadcasters and represented an integral part of many of their reports on Israel and the Palestinian territories. The events under analysis in the 2006-2008 comparison period occurred at a time when the media was not only about to enter a period of significant change in view of technological developments (i.e. in social media, social networks, and citizen journalism in its infancy), but also when political change in the region was looming in the shape of the Arab Spring in 2011. This is not to say that this period

\footnotetext{
${ }^{3}$ Chris Flood, Stephen Hutchings, Galina Miazhevich and Henri Nickels, 'Between Impartiality and Ideology: the BBC's Paradoxical Remit and the Case of Islam-Related Television News', Journalism Studies, 12 (2011), pp. 221-38.

${ }^{4}$ Louise Fawcett, International Relations of the Middle East (Oxford: Oxford University Press, 2005).

(c) School of Slavonic and East European Studies, University College London, 2014.
} 
represented a lull in global war and conflict climate. Far from it, given the fallout from the events surrounding 9/11 including the then on-going situation in Afghanistan and Iraq and the many acts of violence, such as attacks and bombings, which occurred globally.

\section{THE REPORTING COUNTRIES}

The choice of the three reporting countries for the analysis is compelling, given their many cultural parallels with the Middle East region. They have all suffered from rising domestic Islamophobia and anti-Semitism, occurrences of which increase in response to flashpoints in the Middle East. ${ }^{5}$ France has the largest Muslim and Jewish communities in Europe (3.8 million and 0.48 million people respectively), ${ }^{6}$ with the UK not far behind (2.7 million and 0.29 million people respectively). ${ }^{7}$ All three support the so-called War on Terror, and Russia aligns itself with the West in this because of its conflicts with Chechnya, the acts of terrorism in Russia, and the rise in Islamic militancy and nationalism within the country. ${ }^{8}$ Media representation of Britain's military involvement in Iraq and Afghanistan has resulted in widespread portrayals of Muslim Otherness, despite the government's policies on multiculturalism and integration. In France the then controversial ban on wearing hijabs (and other religious symbols) in French state schools led to public unrest and

\footnotetext{
${ }^{5}$ For background data on Islamophobia, see: 'Synthèse du rapport sur l'islamophobie en France, 2008, Report', (Collectif Contre 1'Islamophobie en France, 2008), <http://www.islamophobie.net/rapports/synthese-rapport2008.pdf $>$ [accessed on 12 March 2012]; Roland Dannreuther, 'Russia, the Middle East and Political Islam: Internal and External Challenges', in Russia and Eurasia Programme Seminar Summary (Chatham House, 2009); 'Understanding Muslim Ethnic Communities', Summary Report (Department for Communities and Local Government, HM Stationery Office, 2009).

${ }^{6}$ For statistics on Muslim population in France, see: Jerome Fourquet, 'Analyse : 1989-2011, Enquête sur l'implantation et l'évolution de l'Islam de France' (Institut Français d'Opinion Publique, 2011); for statistics on Jewish population in France and the UK, see: 'The Jewish Population of the World', Jewish Virtual Library (2010), <http://www.jewishvirtuallibrary.org/jsource/Judaism/jewpop.html> [accessed on 7 February 2012]. ${ }^{7}$ For statistics on the Jewish population in the UK, see: 'What does the Census tell us about religion in 2011?', 2011 Census (Office for National Statistics, 2013), <http://www.ons.gov.uk/ons/rel/census/2011census/detailed-characteristics-for-local-authorities-in-england-and-wales/sty-religion.html> [accessed on 9 October 2013]; 'The Jewish Population of the World'.

${ }^{8}$ For a range of opinions on Russia's approach to the War on Terror see: Stephen Blank, 'An Ambivalent War: Russia's War on Terrorism', Small Wars \& Insurgencies, 14 (2003), pp. 127-150; John Russell, Chechnya Russia's 'War on Terror' (Abingdon: Routledge, 2007); Nathan Thornburgh, 'Russia's Long (and Brutal) War on Terror' (2010), <http://content.time.com/time/magazine/article/0,9171,2008890,00.html> [accessed on 1 February 2013]; Simon Shuster, 'How the War on Terrorism Did Russia a Favor' (2011), <http://content.time.com/time/world/article/0,8599,2093529,00.html> [accessed on 1 February 2013].
} 
allegations of discrimination. ${ }^{9}$

The shift from Chirac's pro-Arab policies to Sarkozy's more centrist strategy, and even to a pro-Israel stance, aimed to promote France's diplomatic role, shapes a complex approach to Jews and Muslims within the French secular and egalitarian legislative framework. Finally, Russia has close links to the Islamic world through its historically embedded indigenous Muslim population, and its various economic and military relations with many of the Middle East's neighbours. ${ }^{10}$ It also appears keen to extend its cultural ties to the substantial Russian-speaking diaspora in Israel.

As will be demonstrated below, analysis of reporting over this period showed certain fundamental differences in the broadcasters' representations of the Middle East as a result of their individual framing practices. News at Ten stood apart by prioritising coverage from within the Palestinian territories, emphasising conflict coverage, and humanitarian issues to the exclusion of most general interest news stories. Indeed, the Middle Eastern conflict had been selected as the principal case study because of the very fact that it did not just include violent displays of fighting, but also the daily lives of those in the region, something which is predominantly ignored by News at Ten. 20 Heures provided broader coverage showing information about events in Lebanon, everyday life in Israel, and various religious events. Particular importance was attached to news stories with any link to France, its leaders or its citizens, highlighting the close links between France Télévisions and the French state; ${ }^{11}$ while Vremya aired an even broader scope in its reporting by including many non-conflict related stories, particularly covering Israel and its Russian-speaking diaspora. Again, the Middle East is not purely a site of conflict, yet Vremya uses the conflict narrative, interwoven with Israel's anniversary celebration, to emphasise the close connections between Russia and the Russian-speaking diaspora in Israel, the role of its leaders, and of Russians in general.

\section{FRAMING}

This paper uses the concept of 'framing', developed by Dietram Scheufele after Robert Entman, as its methodological tool - a technique seen to be used by news providers to help viewers 'make sense' of the world by filtering vast amounts of

\footnotetext{
${ }^{9}$ 'Loi N² 2004-228 Du 15 Mars 2004 Encadrant, En Application Du Principe De Laïcité, Le Port De Signes Ou De Tenues Manifestant Une Appartenance Religieuse Dans Les Écoles, Collèges Et Lycées Public', Legifrance.gouv.fr website, <http://www.legifrance.gouv.fr/affichTexte.do?cidTexte=JORFTEXT000000417977\&dateTexte=> [accessed on 12 January 2012].

${ }^{10}$ Dannreuther, 2009.

${ }^{11}$ Raymond Kuhn, The Media in Contemporary France (Maidenhead: Open University Press, 2011), pp. 89-100.

(c) School of Slavonic and East European Studies, University College London, 2014.
} 
information and contextualising it in terms of background frames of reference. ${ }^{12}$ This results in the omission of material and the manipulation of the remaining material to provide a constructed version of an event which coincides with, and is shaped by, the reporting country's cultural values. Frames, or framing, is described by Edelman as a process during which the 'character, causes and consequences of any phenomenon become radically different as changes are made in what is prominently displayed, what is repressed and especially in how observations are classified'. ${ }^{13}$ This is supported by Entman who defines this practice as being the selection of 'some aspects of a perceived reality [making] them more salient in a communicating text, in such a way as to promote a particular problem definition, causal interpretation, moral evaluation, and/or treatment recommendation'.14 Frames can be influenced by society's values, the ideology and policies of journalists and elites, and can complement the public salience of a topic by media emphasis on certain attributes of that topic. ${ }^{15}$ In the case of foreign conflict reporting, negative or positive emphasis may be placed on either of the conflicting sides, on particular leaders, or on particular strategies, whilst others may be omitted altogether therefore reducing their corresponding salience. Thus, news channels can selectively frame, or shape news items using various techniques such as omission, images, voices, verbal texts, and via the use of juxtaposition, all of which will be examined here.

\section{CASE STUdY}

The Sixtieth Anniversary of the state of Israel was celebrated on 8 May 2008 with military displays involving warships and aircraft, parachute landings onto Tel Aviv beaches and other public events. The three news providers examined here used similar amounts of airtime in covering the occasion. This one-day event was portrayed differently by the three news providers, resulting in the respective domestic audiences receiving varying representations of a single occurrence. It is a useful event to discuss as it afforded the news providers wide-ranging opportunities for differing representations, as they had a choice of focusing either on Israel, the

\footnotetext{
${ }^{12}$ Dietram Scheufele, 'Framing as a Theory of Media Effects', Journal of Communication, 49 (1) (1999), pp. 103-122.

${ }^{13}$ Murray Edelman, 'Contestable Categories and Public Opinion', Political Communication, 10 (1993), pp. 231242.

${ }^{14}$ Robert M Entman, 'Framing: Toward Clarification of a Fractured Paradigm', Journal of Communication, 43 (4) (1993), pp. 51-58.

${ }^{15}$ Scheufele; Pamela Shoemaker and Timothy Vos, 'Media Gatekeeping', in An Integrated Approach to Communication Theory and Research, ed. by Don W. Stacks and Michael Brian Salwen (Abingdon: Routledge, 2009), pp. 75-90.
} 
history of Israel, the repercussions of Israel's creation for the Palestinians, or the situation following its creation.

Initial introductory information on the anniversary provided by the broadcasters was similar, but differences quickly became apparent as their own framing techniques and practices emerged: News at Ten provided a report about Israel's creation in 1948 using images from a kibbutz but then went on to discuss and interview Palestinians who had had their property confiscated as a result. It provided editorial summaries about the present-day situation and possible solutions to the on-going conflict. 20 Heures reported on the activities of a group of Israeli volunteer doctors travelling to the Palestinian territories to provide medical care to Palestinians. However this section of the news item appeared unrelated to the celebrations introduced at the start. Vremya's reports focused purely on Israel throughout describing the celebrations and providing information from before, and during, the War of Independence in 1948. The case study shows how Vremya appears to use an event and manipulate it in order to divert attention from the conflict as a whole to concentrate on Russian ties with the region. In order to provide a contextual comparison for Vremya's coverage of the events, and emphasize certain characteristics of Russian state-aligned foreign news provision, the article will now discuss the reports by News at Ten and 20 Heures.

\section{NEWS AT TEN ${ }^{16}$}

A specific and distinguishing characteristic of the $\mathrm{BBC}$, represented here by its evening news programme News at Ten, is the requirement to ensure 'due' impartiality which, according to its Editorial Guidelines, 'lies at the heart of public service and is the core of the BBC's commitment to its audiences' ${ }^{17}$ This same section in the Guidelines goes further stating that, 'news in whatever form must be treated with due impartiality, giving due weight to events, opinion and main strands of argument' ${ }^{18}$ Despite this, extensive criticism from all sides has been directed at the $\mathrm{BBC}$ and its news provision with regard to bias and lack of objectivity, of which its Middle East reporting is a vivid example. The latter has been subject to widespread discussion in academic literature, ${ }^{19}$ and many enquiries have been conducted into both anti-Israeli and anti-Palestinian biases. The Balen report, an internal report

\footnotetext{
16 'BBC News at Ten', BBC 1, 8 May 2008, 10pm.

17 'Section 4: Impartiality', in Editorial Guidelines, BBC (2013),

<http://www.bbc.co.uk/editorialguidelines/page/guidelines-impartiality-introduction/> [accessed 8 January 2013].

${ }^{18}$ Ibid.

${ }^{19}$ See, for example: Greg Philo and Mike Berry, Bad News from Israel (London: Pluto Press, 2004); Greg Philo, and Mike Berry, More Bad News from Israel, ed. by Glasgow University Media Group (London: Pluto Press, 2011).
}

(C) School of Slavonic and East European Studies, University College London, 2014. 
written in 2004 by Malcolm Balen about the BBC's coverage of the Israeli-Palestinian conflict, resulted in the appointment of a Middle East Editor - Jeremy Bowen - 'to enhance our audience's understanding of the Middle East; and to provide extra commentary, focus and analysis to an increasingly complex area of the world' ${ }^{20}$ This very notion of impartiality, important here and in the analysis to follow, will illustrate how it significantly contributes to, and results in, the specific framing of the events covered here.

News at Ten's coverage of these events was, in fact, not simply a short report as part of the news schedule, as was the case with the other two broadcasters. It was taken from an hour-long documentary, shown on BBC 2, entitled 'The Birth of Israel' and presented by Jeremy Bowen - an indication of the importance attached to this state by the broadcaster beyond the single anniversary event. The three-minute news item on News at Ten was characterised by the latter's endeavours to adhere to its impartiality guidelines and by its continual technique of juxtaposing themes concerning the Israelis and the Palestinians. This resulted in the events being framed so that the humanitarian aspect of war and its futility was emphasised. In fact, the on-going 'futility of war' narrative permeates the overall news agenda and extends to the general programming schedule, illustrating the influence on the news agenda of the UK's ongoing participation in other conflicts.

The introductory words from the anchor, initially accompanied by black and white footage of the 1948 celebrations, then by images of current festivities, leave no doubt about the economic and military success that Israel has achieved since its creation. Yet, there is then an immediate contrast as solemn marches by Palestinians are described verbally and shown visually, being held to mark the Nabka - the displacement of Arabs because of the creation of the state of Israel - instantly raising the issue of the inevitable sacrifices of war and Israel's statehood. Such comparisons are found throughout the news item, superficially implying that both sides of the conflict are being covered and that the guidelines are being adhered to, but in fact, News at Ten's principal contention concerns the tragedy of war. The current Israeli celebrations are juxtaposed with the following images: a 1948 battlefield, preserved at a kibbutz museum; the images of an economically prosperous Israel are contrasted with shelled and impoverished areas in Gaza; an elderly former Israeli soldier who fought for the creation of Israel is contrasted with an elderly Palestinian who lost his home as a result; the Israeli achievements shown at the beginning of the item are contrasted in the end with the images of Israel's spoils of war being framed both visually and verbally as 'only a few bits of rubble'. Jeremy Bowen, as the

\footnotetext{
20 'BBC News Appoints Jeremy Bowen as Middle East Editor', BBC Press Office (2005), <http://www.bbc.co.uk/pressoffice/pressreleases/stories/2005/06_june/16/bowen.shtml> [accessed on 9 November 2012].
} 
Middle East Editor, then speculates on the desperation of the situation, linking this conflict to the $\mathrm{BBC}^{\prime}$ s ongoing narrative concerning the futility of war.

News at Ten shapes its reports so that there are no winners or losers in war. Yet, despite ensuring that both sides of the argument are represented, it is careful to omit the important context which might remind the viewer of its reporting country's involvement in the conflict. Neither the anchor nor the Middle East editor makes any reference to Israel prior to 1948. Any suffering caused to Jews at the time is shown to be either the result of fighting from one of the 'five Arab states that invaded after Israel's declaration of independence' or the Holocaust. Whether or not it observes the impartiality guidelines, this reporting by News at Ten demonstrates the influential role played by television news in reprogramming cultural memory as it manipulates the remembering and forgetting of an existing reporting country's role in a conflict. ${ }^{21}$ Due to the purposeful omission of Britain's connection to the region, Britain appears outside the conflict.

News at Ten, therefore, provides a complex news report justifying the creation of Israel whilst portraying it alongside Palestinian displacement and dispossession. Because of its prevailing technique of juxtaposing contrasting frames, it appears that both sides in the conflict are represented, yet the broadcaster also manages to implicitly convey the evaluative message of the 'victors and victims' of war. Thus, News at Ten frames an event - which could have been just a short report acknowledging an anniversary - in such a way that the focus is shifted to make the conflict a central part of the item.

\section{HEURES 22}

Although the concept of impartiality is not stressed to the same extent in France Télévisions' Charter as it is in the BBC Guidelines, 20 Heures, as a public sector broadcaster, is still obliged to ensure the independence of its reports from pressure from ideological, political, economic, social, and cultural groups. ${ }^{23}$ French public broadcasting does, however, have a long history of state intervention, and ongoing challenges, apparent here, emerge in its reports which oscillate between supporting state policy and maintaining its own independence. ${ }^{24}$

\footnotetext{
${ }^{21}$ Maurice Halbwachs. On Collective Memory (London: University of Chicago Press, 1992).

22'Journal de 20 heures', France 2, 8 May 2008, 8pm.

23 'Charte Des Antennes De France Télévisions', France Télévisions (2010), p. 65,

<http://www.francetelevisions.fr/downloads/charte_des_antennes_web.pdf> [accessed 25 April 2012].

${ }^{24}$ For a history of state intervention, see: Raymond Kuhn, The Media in France (London: Routledge, 1995);

Raymond Kuhn, The Media in Contemporary France (Maidenhead: Open University Press, 2011).

(C) School of Slavonic and East European Studies, University College London, 2014.
} 
Since Sarkozy came to power in 2007, the President in spite of France wanting 'to be involved in advancing an Israeli-Palestinian agreement', 25 frequently made statements such as 'Israel's security is a clear red line that is not negotiable', 26 and 'Israel can count on my support to spur, under the - well-timed - upcoming French Presidency, new momentum in its relationship with the European Union', ${ }^{27}$ marking a shift in policy from Chirac, his predecessor. When emphasising France's commitment to the Quartet and the EU, Sarkozy also clearly implied that he was prepared for France to negotiate with Palestine, but that the latter would not include the democratically-elected Hamas. He instead focused on the Palestinian Authority and its President who, according to Sarkozy, 'know my feelings of friendship and respect towards their people [my translation]' ${ }^{28}$ It is in accordance with this stance that 20 Heures' support for Israel and the latter's security emerged throughout its news items, demonstrating, on one hand, a level of alignment with state policy potentially greater than that found on News at Ten - and highlighting, on the other, its reporting country's pursuit of a new diplomatic role, either alone or in association with the EU.

However, tensions do emerge in 20 Heures' portrayal as the broadcaster struggles between presenting Sarkozy's pro-Israeli stance, apparent in many of its news items, and one which questions the benevolence of the Israelis, represented here by the work of association Physicians for Human Rights - Israel. ${ }^{29}$ As on News at Ten, a positive portrayal of an economically successful Israel is shown in the introduction but then, rather than continuing its focus on the celebrations, 20 Heures reports on the work of this Association and follows its mainly Israeli volunteer doctors as they set up temporary pharmacies and clinics, offering medical care to those in the West Bank. Images of the 'three hundred patients awaiting them [my translation from here onwards]' are shown in an isolated village with close-ups of infants being examined and also minor surgery being carried out.

This association is used as the main voice of the item and is portrayed as the human face of Israel, providing much-needed medical attention to Palestinians. It is,

\footnotetext{
${ }^{25}$ Aluf Benn, 'Sarkozy Tells PM: Palestinian Refugees Will Not Return to Israel' (2007), <http://www.haaretz.com/news/sarkozy-tells-pm-palestinian-refugees-will-not-return-to-israel-1.231605> [accessed 13 June 2011].

${ }^{26}$ Roni Bart and Limor Simhony, 'Israel and the International System', in The Middle East Strategic Balance 2007-2008 (2008), pp. 11-20; Beatrice Patrie and Emmanuel Espanol, Méditerranée: Adresse Au Président De La République M. Nicolas Sarkozy (Paris: Sinbad, 2008).
}

${ }^{27}$ 'Text of French President Nicolas Sarkozy's Speech at Crif', AJC Global Jewish Advocacy (2008), <http://www.ajc.org/site/c.ijITI2PHKoG/b.3908711/> [accessed 02 October 2012].

28 'XVème Conférence Des Ambassadeurs', France Diplomatie website, 27-29 August (2007), <http://www.diplomatie.gouv.fr/fr/les-ministres-et-le-ministere/evenements-11561/conference-desambassadeurs/precedentes-conferences/xveme-conference-des-ambassadeurs/article/allocution-de-m-nicolassarkozy-a> [accessed 02 October 2012].

29 'Mission \& History', Physicians for Human Rights - Israel (2011),

<http://www.phr.org.il/default.asp?PageID=145> [accessed 13 April 2011].

(C) School of Slavonic and East European Studies, University College London, 2014. 
in fact, a human rights organisation whose mission statement declares that 'Israel's prolonged occupation over Palestinian territory is the basis of human rights violations [...] [f] or this reason we oppose the occupation and endeavour to put an end to it', ${ }^{\prime 0}$ yet any context about it is omitted and, as a result, it is not clear that its actions are not necessarily those of the Israeli state. Information about the conflict itself is also omitted: there is no context about why the work of this Association is needed, or whom it is caring for. Even the patients, who receive treatment from these volunteer doctors, are not suffering from conditions which are conflict-related, distancing Israel from any part in the present-day fighting. Indeed, following the short introduction, further details, current or past, about Israel as a state, are omitted and the main part of this item appears unrelated to its introduction. Thus, 20 Heures, appearing to be in alignment here with state policy, provides an incomplete and complex representation in which Israeli role in the conflict is ignored, yet its apparent role in assisting those now living in hardship because of the conflict appears to be lauded.

Because of this framing, both sides in the conflict, superficially, appear to be represented in an equivalent manner: the Israelis, through this association, are presented positively, extending a hand of friendship to the Palestinians, and the latter are portrayed gratefully accepting a momentary solution to their lack of access to medical care. Yet, the practice of using contrasting frames, visual images and omission results in the two sides in the conflict not being presented in an equivalent manner and an interpretation, which appears to be pro-Israeli, is supported by the words of a young Palestinian man who states, after he has received medical assistance from the association, that, 'there are good Israelis who treat Palestinians humanely'. 20 Heures, however, also includes his next sentence, which could easily have been omitted, that 'other [Israelis] want us to leave', illustrating how the news provider remains independent of the prevailing stance of Sarkozy's government, an important characteristic as 20 Heures strives to confirm its impartiality as a public broadcaster. The correspondent reinforces this stance by casting doubt on, and even being critical of, Israeli actions, again quoting this same patient and his family, stating that 'they say that not all the Israelis are necessarily bad [my emphasis],' using reported speech to distance the news provider from such a sentiment. 20 Heures contrasts the care provided by the Israelis with the statement that it is the latter, however, who determines whether the young man will receive permission to return for further treatment, with the implication that, far from being the benefactor, this situation only serves to reinforce their control over the lives of the Palestinians who, in turn, can only be perceived to be the victims. This lack of equivalence continues to emerge as differences in material portraying the Israelis and the Palestinians are

\footnotetext{
${ }^{30} \mathrm{Ibid}$.
}

(C) School of Slavonic and East European Studies, University College London, 2014. 
emphasised in images, including the many physical barriers and roadblocks which encumber the Palestinians' lives, accentuating the Palestinian cause and the hardship suffered by its people.

In accordance with its remit, 20 Heures endeavours to present two sides of the conflict. However the disparity in the coverage, the omission of context and editorial interpretation, which could have been used to clarify such gaps, result in an unclear message. On one hand, the news provider's reports appear to highlight the state's pro-Israel stance in presenting it, via the association, as a benefactor providing aid to the Palestinian civilians who are allocated a purely victim status. Yet, on the other hand, the coverage appears critical of the appropriateness of Israel's magnanimity in a situation to which it is a major contributor.

\section{VREMYA $^{31}$}

It is against the context of these public sector broadcasters, that Vremya's framing of foreign news and promotion of its home country, either explicitly or by disparaging others, can be discussed. The date of this anniversary coincides with the run-up to Victory Day celebrations in Russia, held on 9 May - an event which has been elevated by Putin in order to promote unity within his country and re-introduce a sense of identity and pride, missing after the collapse of the Soviet Union and Russia's economic crisis in the 1990s. The 2005 Sixtieth Victory Day celebrations, held only three years earlier in Red Square and throughout Russia, were on a monumental scale. ${ }^{32}$ The Victory Day is in apparent juxtaposition to Israel's Anniversary celebrations in Vremya's coverage of the event. The commemorations in Israel, although not necessarily negatively covered by Vremya, are framed using techniques such as inclusion, omission, verbal, and visual emphasis to promote the Russian state, reflecting Vremya's role as state-aligned broadcaster.

Vremya makes no reference to Israel's success, economic, military, or otherwise. This is in stark contrast to the other two news providers where its accomplishments are lauded, if only in the introduction. Instead, Israel's attempts at celebrations are disparaged, not necessarily as a deliberate act of belittlement, although this is indeed possible given the state's close ties to the US and the anti-US sentiment which permeates Vremya's news schedule, but rather so that they can be

\footnotetext{
31'Vremya', Channel 1, 8 May 2008, 9pm.

${ }^{32}$ For details of this commemoration as a media event, see: Stephen Hutchings and Natalia Rulyova, 'Commemorating the Past/Performing the Present: Television Coverage of the Second World War Victory Celebrations and the (De)Construction of Russian Nationhood', in The Post-Soviet Russian Media: Conflicting Signals, ed. by Birgit Beumers, Stephen Hutchings and Natalia Rulyova (Abingdon: Routledge, 2009), pp. 137157.
} 
used as a reference against which Russia's parallel superior celebratory efforts can be measured.

The Israeli celebrations are not viewed in isolation. Implicit verbal comparisons [appearing from here onwards in my translation], by both Vremya's anchor and its correspondent, are apparent from the outset throughout the report. Phrases, such as 'for little Israel [my emphasis]' and 'it even had [my emphasis]', show astonishment at the Israelis' achievements and celebrations, yet disparage them instantly with the statement 'the Israeli parades for the country's independence are far removed from the parades in our traditional understanding of the word'. Vremya's reporter, Yevgenii Sandro, reminds the viewer of Russia's great parades as he describes Israel's attempts as having 'no formations of marching soldiers along the streets or lines of military hardware transported through squares'. Indeed, the comparison goes further and the Israeli celebrations, initially admired in the introduction by the anchor as being 'an impressive presentation', are reduced to being 'more like a show for tourists and holiday makers' and 'true, it wasn't without its crises'. The reporter proceeds to highlight errors in the celebrations. For example, a parachute landing, which is part of the display, is mistimed resulting in several injuries and is rendered even more dramatic by supporting visual images. Again, the diminutive portrayal of Israel is raised as Sandro describes the landing site on the beach as 'quite small' and 'surrounded by the crowd' implying that it is ambitious, even foolhardy, to attempt such a feat and that dangers to the crowd are inevitable. The visual images show the wounded being transported away in a convoy of ambulances whilst the reporter provides statistics of the numbers injured. The manner in which this comparison is used to reinforce a 'superior' Russia, rather than the country of focus, exemplifies the latter's identity crisis, and the implication emerges that this situation would not have occurred during Russian parades.

Similar criticism of the lack of detail when organising the celebrations emerges in Sandro's comments that the official display of Israel's maritime fleet, despite including submarines and naval vessels, happens to be accompanied by yachts which 'appears to be some form of a mistake' and resorts to quoting senior naval officials who state, 'it was meant that way'. If this were not sufficient, Vremya then provides footage of an interview with a flotilla commander whose appearance serves purely to justify the ostensibly bizarre presence of such small yachts in an important maritime parade.

A further framing technique used by Vremya is that of omission, as a result of which attention is deflected from the Middle East conflict to Russia. In this item, there is scant mention of the Palestinian territories, the effect of the creation of Israel on these territories and the Palestinians, or the ongoing conflict. One short sentence by the reporter that 'the conflict is the longest in the world and that the Palestinians are still waiting for their state', is the only occasion when Vremya mentions the 
Palestinians despite the large indigenous Muslim population in Russia and its own close relations with Arab States. By omitting the Palestinian territories and the Palestinians from the report, Vremya raises the salience of Israel - however much it disparages it - as a homeland, like other countries, with everyday events and lifestyle as befits the Russian-speaking diaspora, rather than as just a site of conflict which appears to be the case with News at Ten. Vremya is, therefore, careful to balance its anti-Israeli criticism - the disparagement of which it uses as part of a prevailing approach to raise Russia's national identity - and its pro-diaspora reporting, as Russia recognises the potential influence of this sizeable Russianspeaking community in the geopolitically important Middle East.

This technique of omission is not exclusive to Vremya. For example, throughout the discussion about Israel's creation in 1948, News at Ten, unsurprisingly, makes no reference to Britain's involvement as the Mandatory authority in Palestine. In contrast, Vremya pointedly states that Britain governed this territory and that, according to the UN resolution, two states should have been created. This is not just reported in the verbal text but is reinforced by black and white footage of British officials in the region at the time and also of the UN in session. This framing allows Vremya to 'diagnose' the problem by incriminating Britain for not adhering to the UN resolution and to make 'moral judgements' and, although Vremya does not go so far as to 'offer treatment for their problems', this approach of attributing blame to Britain also distances its own reporting country from the current conflict. ${ }^{33}$

Being a state-aligned broadcaster, these events in Israel hold little interest to Vremya in themselves as they do not contain any aspect which directly concerns Russia. The broadcaster, therefore, has to find any angle to promote Russia and achieves this by continuing its disparagement of other countries. Israel and Britain are not alone in receiving this treatment and soon the attention of Vremya's implicitly disparaging statements is targeted against the US where, rather than using the technique of omission which is apparent on the other two news providers, Vremya opts for inclusion. No mention is made of Israel's economic success, but instead its military prowess is foregrounded with statements such as 'the main heroes of today's festivities are the military' and 'dozens of army bases have organised open days and [...] holiday makers have even been able to meet agents from the secret intelligence school'. Yet this information is included so that it can be associated, however briefly, with the US's provision of arms to Israel. No editorialising comments are provided by the reporter regarding these US-Israeli relations or the military strength of this state, but the mere inclusion of this information is significant as according to Entman 'even a single unillustrated appearance of a notion in an obscure part of the text can be highly salient, if it comports with the existing

\footnotetext{
${ }^{33}$ Entman, p.53.

(C) School of Slavonic and East European Studies, University College London, 2014.
} 
schemata in a receiver's belief systems' ${ }^{34}$ References to US-supplied F-15 and F-16 fighter jets, Hercules transport aircrafts, Apache and Blackhawk helicopters all reinforce the assertion that Israel is the 'main ally of the US in the region' and the 'modern Israeli military equipment is mainly American', serving to emphasise the US's influence in the region and contributing to the anti-US message found in Vremya's reports.

There are instances when Vremya can promote Russia directly, for example, in a short interview with a veteran of Israel's 1948 War of Independence. In order to introduce the veteran, the reporter provides further black and white footage of the fighting and states, in his voice-over, that the illegally formed groups of Jewish fighters were forced into hiding from the British administration, reiterating the latter's association with the region. In the interview, rather than discussing the fighting, or the creation of Israel, the veteran instead is used to convey the positive influence of Russia in their fight for independence: 'We were entranced by the Russian partisan movement, we wanted to be like them, we even sang Russian songs'. The emphasis is on 'Russian' and all associations with, and references to, 'Soviet' have been omitted allowing all credit, or recognition, for contributing to the creation of this state - whose celebrations are the focus of this news item - to be given to the current regime in Russia.

Vremya does provide some information about the anniversary. As mentioned above, it refers to the state of Israel leading up to its creation and also to the celebrations but it could be speculated that, had it not coincided with Victory Day in Russia - an event which is stressed as being culturally important for its national identity - it might not have been considered sufficiently newsworthy to be aired. In fact, in contrast to the other two news providers which represent, to whatever degree, both sides in the ongoing conflict, possibly in recognition of the ethnic composition of their respective populations, Vremya's promotion of Russia appears more important than the possible domestic repercussions of omitting information about Palestine following the creation of Israel.

This does, indeed, appear to be representative of Vremya's coverage of the conflict, and an ongoing narrative centred on promoting Russia at the expense of arousing possible domestic tensions is apparent. Although this case study demonstrates Vremya's desire to endorse Israel as a suitable location for the Russianspeaking diaspora, this approach of promoting the reporting country equally emerges in other items including Israel and the Palestinian territories, either together or in isolation. In such reports, and in contrast with the News at Ten's approach of ensuring that the conflict is the focal point, Vremya 'de-conflictualises' the events it

${ }^{34} \mathrm{Ibid}$.

(C) School of Slavonic and East European Studies, University College London, 2014. 
covers and re-frames them to include an angle on Russia. This reflects the manner in which this state-aligned news provider focuses on promoting Russia's status and the extent to which this appears to take priority over the complex combination of the influential diaspora in Israel and Russia's multi-layered ties to the Islamic world.

\section{CONCLUSION}

By comparing Vremya's framing of events with those of News at Ten and 20 Heures, this article has illustrated how the Russian broadcaster manipulates its coverage to divert attention away from the conflict itself to focus on its own country. Differences and similarities between the broadcasters' representations have emerged in two main areas: the first of these relates to their regulatory structures and the second concerns their framing practices. The influential role played by the broadcasting regulations imposed on News at Ten and 20 Heures emerges in their reports as they endeavour to adhere to their impartiality and independence remits. Both, to an extent, present the two sides of the conflict thus respecting their various guidelines and procedures. However, despite these constraints, their framing techniques and practices result in reports which still emphasise particular aspects favoured by the news provider.

The duration of each news item is only slightly longer than three minutes, yet the broadcasters managed to include large quantities of information and to shape it in such a manner that each presented a totally different view of the Anniversary events. Their practices largely concur with definitions of framing as they placed negative or positive emphases on certain culturally relevant aspects of the events, thus highlighting the influence of their own reporting country's values and policies on television news reporting. News at Ten framed the report, in particular, by juxtaposing images to highlight its prevailing futility of war narrative whilst 20 Heures, through its use of both omission and contrasting visual images, appeared torn between representing the pro-Israeli stance of the then French government and questioning the actions of the Israelis in its coverage of Israeli volunteer doctors.

Vremya, in contrast, being a state-aligned broadcaster, rather than a public sector broadcaster, was not subject to the same stringent journalistic regulations. It was therefore able to manipulate its coverage of events to include an angle which would be beneficial to Russian identity. Omission was the dominant tool used to frame the events which proved effective as Vremya only presented one side of an argument, without comment or interpretation. It did not provide context to the ongoing conflict and the viewpoint of the Palestinians was absent. Vremya, in this instance, portrayed Israel as a discrete state with no connections to the broader Middle East or the conflict regardless of how this might impact on its diverse 
relations with both the Islamic and the Arab World. Instead, counter-arguments, which might have eclipsed the item's message, were simply omitted. This was particularly apparent when contrasted with the two-sided arguments proffered by News at Ten and 20 Heures. Vremya also, unsubtly used the reporter's text and visual images to boost Russia generally through the constant disparagement of other nations.

Vremya, thus, manipulates this single event to promote its own identity. Although principal information is conveyed to the viewer - the news provider is in part more informative than News at Ten, particularly when covering the pre-1948 period - the manner in which this information is represented serves to promote Russia. Perceiving this manipulation of television news by Vremya merely to be state propaganda, however, would mean contributing to the widespread and increasingly anecdotal use of this term, which is an oversimplification of the media landscape of Russia and does little to acknowledge the disguised instability of the post-Soviet identity. While the relatively more stable national identity of Britain and France allowed 20 Heures and News at Ten to focus on a foreign country's affairs, for Russia identity building remained a priority. It would, perhaps, be more accurate to suggest that Vremya's foreign conflict reporting, as demonstrated by this analysis of its coverage of Israel's Sixtieth Anniversary, stands for the state's unsubtle urge to promote and secure Russian identity at all costs, often lapsing into an undisguised and simplified promotion of its own nationality to secure the diverse and truly complex post-perestroika identity.

This work is licensed under the Creative Commons Attribution-Non-commercial-Share-alike 2.0 UK: England \& Wales License. This license allows for redistribution and alteration, commercial and non-commercial, as long as credit is given to the author. To view a full copy of this license, visit: http://creativecommons.org/licenses/ or send a letter to Creative Commons, 444 Castro Street, Suite 900, Mountain View. 